\title{
Performance Evaluation of Tuntang Watershed based on Quantity and Quality of Water
}

\author{
Ugro Hari Murtiono* and Paimin \\ Research Institute for Forestry Technology on Watershed Management (BPTKP DAS Solo) \\ Jl. Jend. A.Yani, Pabelan, Surakarta 57102,Telp: (0271) 716709 \\ *) Corresponding author (e-mail: uh_murtiono@yahoo.com)
}

\begin{abstract}
The objective of the study was to evaluate the performance of Tuntang Catchment based on water quantity and quality area ranging from its upstream to downstream. The method used to determine the water quantity was by carrying out ground study on water discharge in the dry season (June 2011) in the research site, while the water quality was determined by conducting a laboratory analysis on the samples obtained from the sites in both the rainy and dry season (January and June 2011). The results indicated that the quantity of water discharge in Tuntang River was categorized "good", although it was utilized for many uses such as irrigation, hydropower, and drinking water. Most of water discharges were mainly supplied from the upstream of Rawa Pening Lake. The water quality determined from the parameters of total dissolved solids, conductivity, pH, phosphate, and nitrate could be classified as "good", meanwhile, the turbidity and dissolved oxygen were classified as "poor".
\end{abstract}

Keywords: water quantity, water quality, specific minimum discharge.

\begin{abstract}
Abstrak. Tujuan penelitian untuk mengevaluasi performa DAS Tuntang diukur dari kuantitas dan kualitas air sungai baik dibagian hulu maupun hilir. Metode yang digunakan untuk mengetahui kuantitas air dengan pengukuran aliran air sungai pada musim kemarau (Juni 2011) pada lokasi yang dipilih, sedangkan kualitas air dilakukan dengan cara pengambilan contoh air pada sungai sungai yang masuk ke danau rawa pening pada waktu musim hujan dan kemarau (Januari dan Juni 2011) kemudian dianalisa di laboratorium. Hasil penelitian diindikasikan bahwa kuantitas debit air di sungai Tuntang berada pada kategori 'baik", walaupun air yang keluar dari danau rawapening telah dimanfaatkan untuk berbagai kepentinganseperti irigasi, hidro electrik, dan air minum. Sebagian besar debit air terutama di support dari hulu DAS Rawa Pening. Parameter kualitas air seperti total padatan terlarut (TDS), daya hantar listrik (DHL), pH, phosphat, dan nitrat dikatagorikan "baik", sebaliknya kekeruhan dan oksigen terlarut (DO) diklassifikasikan "jelek".
\end{abstract}

Kata Kunci : Kuantitas, kualitas air sungai, debit minimum spesifik.

\section{Introduction}

Water is a basic requirement for the survival of living beings, including human, animal, and vegetation. However, the water resource availability is increasingly limited within time and space. In Indonesia, the diversity of water resources availability is high based on the area. Java, for instance, is monsoon region with obvious difference between rainy and dry season, the region adjacent to the equator has indistinct differences, and while in Nusa Tenggara is semi-arid regions with low rainfall. Although Indonesia has abundant water resources, yet the scarcity of water and water resources become a fact, especially in urban areas and development centers around them (Pawitan, 2002). Regions are allegedly susceptible to water resources are Java, Bali, Nusa Tenggara, Sulawesi, and Maluku. The performance of catchment can be evaluated from its quality (Duan, et al., 2016; McMillan, 2016; Kageyama, et al., 2016; Supangat and Paimin, 2007), quantity (Pal, et al., 2016; Wang, et al., 2016), and continuity/ sustainability (Brotosusilo, et al., 2016).

The discharge of a watershed in the dry season can be an indicator of the quantity and continuity level of a watershed's water supply. Meanwhile, the water quality in 
the rainy and dry season can be an indicator of water quality of a watershed or a catchment area.

In fact, watershed is a crucial reserve and water supply for many usages such as irrigation, agricultural, industrial, and household consumption. Additionally, watershed captures rainwater to control damaging floods, drought, soil erosion, and sedimentation. Artificial surface water storage such as dams and natural storage such as lakes will be able to provide a continuous water supply in the dry season. One of the lakes in the watershed is Lake Rawa Pening in Tuntang watershed. This lake is absolutely a natural means for further various uses of watershed. Rawa Pening Lake is located in the upstream of Tuntang watershed and has a primary role. This study aimed to evaluate the performance of Tuntang watershed based on the quantity and quality of water, and potential implication to Rawa Pening Lake sustainability.

\section{Research Method}

\section{a. Materials and Tools}

Materials and tools used in this study were basic maps (topography, soil, geology, and land-cover/use), Rupa Bumi Indonesia (RBI) maps, Current meter, suspended load sampler USDH 48, sample bottles, measurement blank forms, sediment, stationeries and computer software, and field-study equipments.

\section{b. Location}

Research was carried out in Tuntang watershed, Central Java, which was divided into three sub-watersheds, namely, Tuntang Hulu sub-watershed, Tuntang Tengah subwatershed, Tuntang Hilir sub-watershed (Figure 1). Lake Rawa Pening is a part of the downstream of Tuntang Hulu sub-watershed. With total area of 2,300 hectares, Lake Rawa Pening which is located in the upstream of Tuntang sub-watershed, Semarang Regency, is vital with its central function as the water source for household and industrial (local government-owned water companies), irrigation for 39,277 ha of paddy-fields, fishery with production of 1,535.9 ton/year, tourism, livestock, peat mining, and hydropower in Jelok and Timo which generate 222.504 million Kwh (Bappeda Provensi Jawa Tengah, 2005).

Catchment area of Tuntang Hulu is affected by the volcanic characteristics of Mount Merbabu (East and Southeast), Mount Telomoyo (South), and Mount Ungaran (West). The west part of Tuntang Tengah subwatershed is affected by Volcano Ungaran while the east part is affected by mixed limestone sedimentary rocks. In addition, Tuntang Hilir sub-watershed is a susceptible mudflat area.

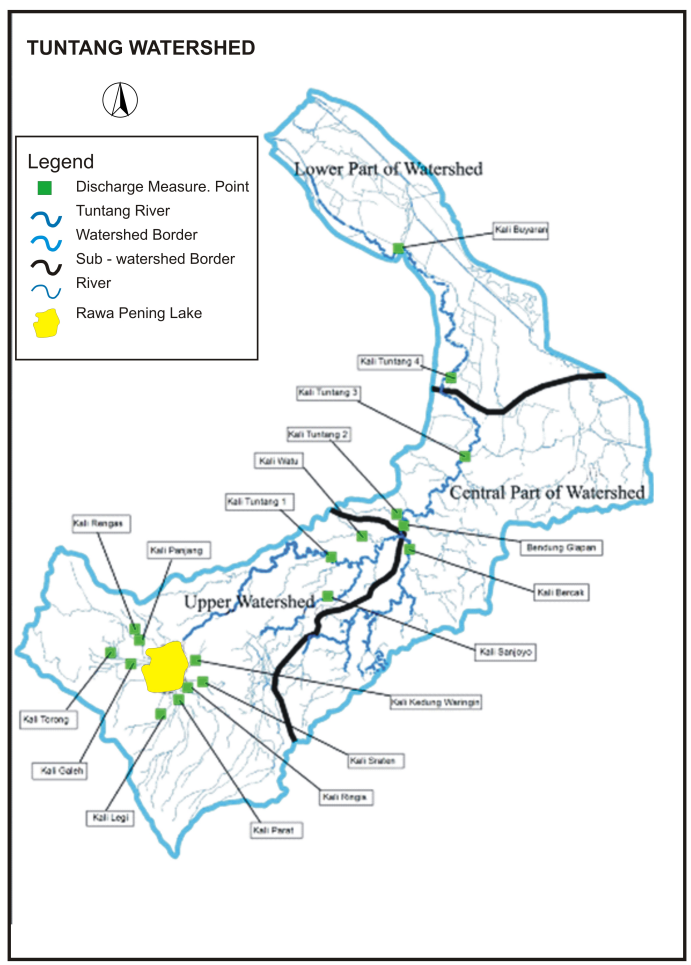

Figure 1. Distribution of Points Discharge Measurement at Tuntang Watershed 


\section{c. Measurement of Water Discharge}

Quantitative measurement of water discharge in Tuntang watershed was carried out in the dry season, while sampling for water quality (qualitatively) was done in the rainy and dry season. Measurements were performed in several points as illustrated in Figure 1, in June 2011. The qualitative discharge measurement in Tuntang Hulu subwatershed was carried out in each inflow to Lake Rawa Pening including 9 (nine) rivers: (1) Kedungwringin River, (2) Ringis River, (3) Sraten River, (4) Parat River, (5) Legi River, (6) Galeh River, (7) Torong River, (8) Panjang River, and (9) Rengas River. In addition, in Tuntang Hulu sub-watershed, measurement was conducted at the downstream of Lake Rawa Pening namely, Tuntang Main River (Tuntang 1), Sanjoyo River, Watu River, and Bercak River. In Tuntang Tengah sub-watershed, measurement was carried out in Tuntang Main River (Tuntang 2 and Tuntang 3) and Glapan Dam (West and East outlet). In Tuntang Hilir sub-watershed, measurement was carried out in Tuntang 4 (adjacent to Grobogan district and Demak district) and Buyaran River.

Discharge measurement involved the measurement of discharge rate and the crosssection area. The cross-section area is divided into six sections. Discharge rate or velocity was measured by current meter on each section (in the middle of the section) and the dimension (depth and width) of each section was measured to obtain the discharge cross-section area. In examining the discharge velocity, current meter was planted in a depth of 0.6 from the surface of the water for the discharge of $<60$ cm water depth; in a depth of 0.2 and 0.8 for the discharge of 60-100 cm water depth; and in a depth of $0.2,0.6$, and 0.8 for the discharge of $>100$ $\mathrm{cm}$ water depth. The produce of discharge rate and cross-section area was the discharge of the section. Total discharge of all sections was the observed water discharge. The value of water discharge $\left(\mathrm{m}^{3 / \mathrm{sec}}\right)$ was converted into a unit of specific water discharge $\left(\mathrm{m}^{3 / s} \mathrm{~km}^{2}\right)$.

Observation on water quality was conducted in the rivers/inflows of Lake Rawa Pening, Tuntang Hulu sub-watershed, and measurement point in the downstream (Buyaran River), Tuntang Hilir sub-watershed. Sample was obtained for water quality analysis was withdrawn in the rainy season (January 2011) and the dry season (June 2011).

\section{d. Data Analysis}

The value of water discharge is stated in specific discharge unit $\left(\mathrm{m}^{3} / \mathrm{sec} / \mathrm{km}^{2}\right)$ by dividing the water discharge with its catchment area $\left(\mathrm{km}^{2}\right)$. Based on Kori (1976), specific discharge $\left(\mathrm{m}^{3} / \mathrm{sec} / \mathrm{km}^{2}\right)$ is classified as: 1$) .<0.015=$ poor; 2$) .0 .015-0.21=$ good; $3) .>0.21=$ very good. From the measurement of the discharge, the quantitative hydrological condition of an area could be determined based on the classification.

Water quality is the quality of water that meets the standards for a particular purpose. Terms are defined as a variety of quality standards in accordance to the intended purpose. Directorate General of Land Rehabilitation and Social Forestry, Ministry of Forestry, 2009, published the category and value for the assessment on the indicators of pollutant content level including the physical, chemical, and biological pollutant as presented in Table 1. These indicators were used as the analytical basis.

Table 1. Classification of Water Quality Parameters

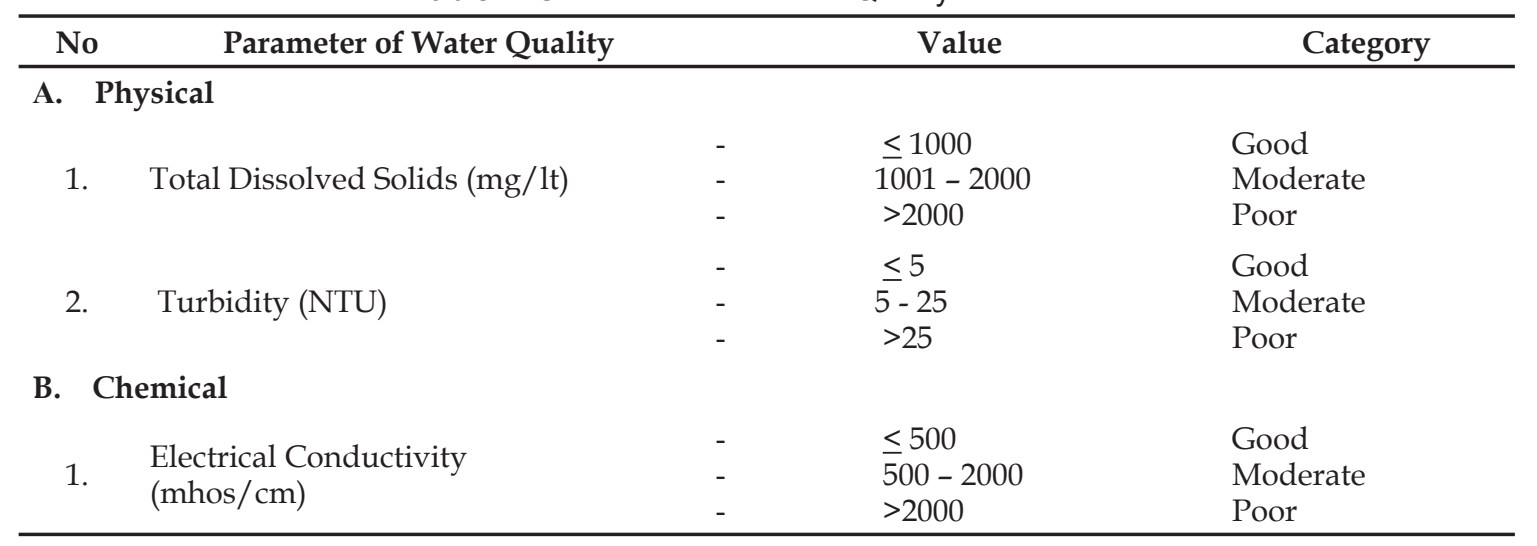




\begin{tabular}{|c|c|c|c|c|}
\hline No & Parameter of Water Quality & & Value & Category \\
\hline 2. & Acidity $(\mathrm{pH})$ & $\begin{array}{l}- \\
-\end{array}$ & $\begin{array}{l}6.5-7.5 \\
5.5-6.5 \text { or } 7.5-8.5 \\
<5.5 \text { or }>8.5\end{array}$ & $\begin{array}{l}\text { Good } \\
\text { Moderate } \\
\text { Poor }\end{array}$ \\
\hline 3. & Phosphate (mg/lt) & $\begin{array}{l}- \\
-\end{array}$ & $\begin{array}{l}\leq 1 \\
1-5 \\
>5\end{array}$ & $\begin{array}{l}\text { Good } \\
\text { Moderate } \\
\text { Poor }\end{array}$ \\
\hline 4. & Nitrate $\left(\mathrm{NO}_{3}\right)$ & $\begin{array}{l}- \\
- \\
-\end{array}$ & $\begin{array}{l}\leq 10 \\
11-20 \\
>20\end{array}$ & $\begin{array}{l}\text { Good } \\
\text { Moderate } \\
\text { Poor }\end{array}$ \\
\hline \multicolumn{5}{|c|}{ C. Biology } \\
\hline 1. & Dissolved Oxygen (mg/lt) & $\begin{array}{l}- \\
- \\
-\end{array}$ & $\begin{array}{l}\geq 6 \\
3-6 \\
<3\end{array}$ & $\begin{array}{l}\text { Good } \\
\text { Moderate } \\
\text { Poor }\end{array}$ \\
\hline
\end{tabular}

Source: Directorate General of Land Rehabilitation and Social Forestry, Ministry of Forestry (2009).

Total Dissolved Solids (TDS) are the solids content in a given volume of water as the result of inorganic compound in the form of suspension or solution. Dissolved solids are total amount of dissolved materials. Turbidity is expressed in a unit of turbidity, also referred to $1 \mathrm{mg} /$ It $\mathrm{SiO}_{2}$ Turbidity is measured by a method of Nephelometric and is expressed in a unit of Nephelometric Turbidity Unit (NTU) (Sawyer and McCarty, 1978).

Electrical conductivity is the measure of water's ability to accommodate the transport of an electric charge whose value is based on the amount of salt dissolved in water, the type of dissolved ions, and water temperature. Conductivity can be used as an instant indicator to determine the levels of ions in the water. The higher is the value, the higher is the ion levels of the water.

The acidity or alkalinity level of water discharge was measured by $\mathrm{pH}$ which is a scale with similar proportion to the concentration of hydrogen ions contained in the water. The $\mathrm{pH}$ scale is valued from 0 to 14 ( $\mathrm{pH}$ of 7 : neutral, $\mathrm{pH}<7$ : acid, and $\mathrm{pH}>7$ : alkaline). The $\mathrm{pH}$ value of 6.5-8.2 is optimum conditions for living beings, on the contrary, too acidic or too alkaline $\mathrm{pH}$ level will be dangerous for them. The acidity level of water environment is affected by several factors, among others, the photosynthesis and biological processes and various types of cations and anions. The increased $\mathrm{pH}$ is influenced by free mineral acid and carbonic acid, while an increased $\mathrm{pH}$ is affected by the amount of carbonates, hydroxides and bicarbonates.

Phosphate is the phosphorus element in the water which can be utilized by plants (Dugan, 1972). Phosphate is derived from the residue of laundry detergent, animal waste, dissolved fertilizer, and other materials. It also functions as nutrients for aquatic plants and it can lead to eutrophication processes. The characteristics of phosphorus can be distinguished from other major chemical elements of the biosphere's constituent elements because it is not contained in the atmosphere. In the earth's crust, the amount of phosphorus is relatively small and easily precipitated. Phosphorus is also an essential element for higher plants and algae as well as for the marine productivity level.

Nitrate $\left(\mathrm{NO}_{3}\right)$ is a form of nitrogen contained in the water derived from soluble fertilizers and animal waste that serves as a nutrient or fertilizer for aquatic plants. High level of nitrate in the water will increase the growth and activity of aquatic plants, in consequence, there will be the depletion of oxygen in the water, which may cause death to aquatic animals. It is called the eutrophication.

Dissolved Oxygen is the amount of oxygen in the water derived from the oxygen in the air and the photosynthesis of aquatic plants. The Earth's atmosphere contains approximately $210 \mathrm{ml} / \mathrm{tt}$ of oxygen. Levels of dissolved oxygen in natural waters are varied depending on the temperature and altitude. In addition, the smaller is the atmospheric pressure, the lower is the level of dissolved oxygen. An increase of the temperature of $1^{\circ} \mathrm{C}$ will enhance approximately $10 \%$ oxygen consumption (Brown, 1987). Decomposition of organic materials and oxidation of inorganic materials can reduce the level of dissolved oxygen to zero (anaerobic). Dissolved oxygen is essential for the aquatic animals and plants. The oxygen content in water is less than in air, the oxygen content of flowing water is higher than the pooled water, and the depletion of oxygen may cause the aquatic plants or animals to thrive difficulty. 


\section{Result and Discussion}

\section{a. Water Quantity}

Result of observations on water discharge $\left(\mathrm{m}^{3} / \mathrm{sec}\right)$ in Tuntang watershed in the dry season was converted into a unit of specific discharge $\left(\mathrm{m}^{3} / \mathrm{sec} / \mathrm{km}^{2}\right)$ as presented in Table 2.

Based on the classification of specific minimum discharge, the inflow of Lake Rawa Pening in the dry season was classified as "good" and "very good" (Kori, 1976), except for Rengas River. The highest specific minimum discharge was derived from, respectively,
Sraten catchment area $\left(0.6485 \mathrm{~m}^{3} / \mathrm{sec} / \mathrm{km}^{2}\right)$ and Kedungringin River $\left(0.2006 \mathrm{~m}^{3} / \mathrm{sec} /\right.$ $\mathrm{km}^{2}$ ). Water is temporary stored in the lake as water surplus in the surcharge storage before being released outside the dam. Total water discharge of $8.0309 \mathrm{~m} 3 / \mathrm{sec}$, in the downstream furthermore was utilized for hydropower, drinking water and irrigation. Although it has been used along its flow, the discharge of Tuntang River (observation of Tuntang River 1) was still in the category of "good" with a specific minimum discharge of $0.069 \mathrm{~m} 3 / \mathrm{sec} / /$ $\mathrm{km}^{2}$

Table 2. Discharge Measurement in Tuntang Watershed (June 2011)

\begin{tabular}{lccccc}
\hline No & $\begin{array}{c}\text { Points of } \\
\text { Measurement }\end{array}$ & $\begin{array}{c}\text { Discharge }\left(\mathrm{m}^{3} /\right. \\
\mathrm{sec})\end{array}$ & $\begin{array}{c}\text { Area } \\
(\mathrm{km} 2)\end{array}$ & $\begin{array}{c}\text { Specific discharge } \\
\left(\mathrm{m}^{3} / \mathrm{sec}^{2} / \mathrm{km}^{2}\right)\end{array}$ & $\begin{array}{c}\text { Vulnerability } \\
\text { level }\end{array}$ \\
\hline
\end{tabular}

I. Tuntang Hulu Sub-watershed

A. Lake Rawa Pening Catchment Area

1. Kedungwringin River $\quad 1.8384$

2. Ringis River $\quad 0.1110$

3. Sraten River $\quad 1.5240$

4. Parat River

0.0711

0.2650

1.5450

1.3248

0.2730

9.18

0.2006

3.47

0.0320

Very good

5. Legi River

2.35

0.6485

37.44

0.0416

Good

6. Galeh River

9.32

0.0284

Very good

7. Torong River

61.21

0.0252

Good

8. Panjang River

26.87

0.0493

Good

9. Rengas River

1.0786

48.93

0.0056

Good

B. Sanjoyo River

2.524

51.277

0.0616

Good

17.51

Poor

Good

C. Tuntang River 1

5.348

76.841

0.049

Good

D. Watu River

0.009

12.947

0.069

Good

E. Bercak River

0.367

135.31

0.001

Poor

II. Tuntang Tengah Sub-watershed
A. Tuntang River 2
Glapan Dam:
B. a. East outlet
b. West outlet
C. Tuntang River 3

7.122

34.088

1.000

91.488

3.034

39.396

0.011

0.077

Poor

2.160

196.97

0.011

Good

Poor

Poor

III. Tuntang Hilir Sub-watershed

\begin{tabular}{|c|c|c|c|c|c|}
\hline A. & Tuntang River 4 & 6.559 & 173.78 & 0,038 & Good \\
\hline B. & Buyaran River & 5.281 & 130.13 & 0,041 & Good \\
\hline
\end{tabular}

The inflows into Tuntang Hulu subwatershed consisted of Tuntang River (5.348 $\left.\mathrm{m}^{3} / \mathrm{sec}\right)$, Sanjaya River $\left(2.524 \mathrm{~m}^{3} / \mathrm{sec}\right)$, Watu River $\left(0.009 \mathrm{~m}^{3} / \mathrm{sec}\right)$ and Bercak River $\left(0.367 \mathrm{~m}^{3} /\right.$ sec). Despite of the "poor" specific minimum discharge of Watu River and Bercak River, the overall discharge of Tuntang River could be considered as "good" as demonstrated in observation result of Tuntang River 2. Sanjaya River which could be categorized as "good" had relatively high water supply to Tuntang Hulu sub-watershed.

Adequate water discharge is utilized mainly for irrigation through Glapan Dam adjacent to Tuntang River. Regarding with this utilization, the discharge in the downstream 
as demonstrated in the observation result of Kali Tuntang 3, becomes very small and in "poor" condition. Nevertheless, the discharge of Tuntang River into Tuntang Hilir subwatershed could be categorized as "good", as shown in the observation result of Tuntang River 4 and Buyaran River. It indicated the water supply from the streams of Tuntang River was relatively high. In accordance to the analysis of water discharge in the dry season, the potential of Tuntang River supplied by Rawa Pening Lake to the downstream was fairly stable.

\section{b. Water Quality}

The parameters of water quality observed in this study included 7 (seven) parameters of: 1). Turbidity, 2). Total Dissolved Solids (TDS); 3). Conductivity (Electrical conductivity); 4). Acidity ( $\mathrm{pH})$; 5). Phosphate; 6). Nitrate $\left(\mathrm{NO}_{3}\right)$; and 7). Dissolved Oxygen (DO). Results on water quality examination in the rainy and dry season in each observation point are presented in Table 3. Generally, the condition of waster quality of Tuntang watershed was "good", except for the parameters of turbidity and dissolved oxygen (DO).

Table 3. Analysis on Water Quality in the Rainy and Dry Season in Tuntang Catchment Area.

\begin{tabular}{|c|c|c|c|c|c|c|c|c|}
\hline No & $\begin{array}{c}\text { Parameter/ } \\
\text { Unit }\end{array}$ & Season & $\begin{array}{l}\text { Parat } \\
\text { River }\end{array}$ & $\begin{array}{l}\text { Sraten } \\
\text { River }\end{array}$ & $\begin{array}{l}\text { Legi } \\
\text { River }\end{array}$ & $\begin{array}{c}\text { Panjang } \\
\text { River }\end{array}$ & Galeh River & $\begin{array}{c}\text { Buyaran } \\
\text { River }\end{array}$ \\
\hline \multirow[t]{2}{*}{1.} & \multirow[t]{2}{*}{$\begin{array}{l}\text { Turbidity } \\
(\mathrm{mg} / \mathrm{lt})\end{array}$} & Rainy & $\begin{array}{l}54 \\
(P)\end{array}$ & $\begin{array}{c}324 \\
(\mathrm{P})\end{array}$ & $\begin{array}{l}207 \\
(P)\end{array}$ & $\begin{array}{l}634 \\
(\mathrm{P})\end{array}$ & $\begin{array}{l}660 \\
(P)\end{array}$ & $\begin{array}{l}30 \\
(P)\end{array}$ \\
\hline & & Dry & $\begin{array}{l}29 \\
(P)\end{array}$ & $\begin{array}{c}3 \\
(G)\end{array}$ & $\begin{array}{c}12 \\
(\mathrm{M})\end{array}$ & $\begin{array}{c}15 \\
(\mathrm{M})\end{array}$ & $\begin{array}{l}26 \\
(P)\end{array}$ & $\begin{array}{c}24 \\
(\mathrm{M})\end{array}$ \\
\hline \multirow[t]{2}{*}{2.} & \multirow[t]{2}{*}{$\begin{array}{c}\text { TDS } \\
(\mathrm{mg} / .1 \mathrm{t})\end{array}$} & Rainy & $\begin{array}{l}88 \\
(\mathrm{G})\end{array}$ & $\begin{array}{l}67 \\
(\mathrm{G})\end{array}$ & $\begin{array}{l}56 \\
(\mathrm{G})\end{array}$ & $\begin{array}{l}64 \\
(G)\end{array}$ & $\begin{array}{l}59 \\
(\mathrm{G})\end{array}$ & $\begin{array}{l}126 \\
(G)\end{array}$ \\
\hline & & Dry & $\begin{array}{l}105 \\
\text { (G) }\end{array}$ & $\begin{array}{l}115 \\
(G)\end{array}$ & $\begin{array}{l}83 \\
(\mathrm{G})\end{array}$ & $\begin{array}{l}137 \\
(\mathrm{G})\end{array}$ & $\begin{array}{l}115 \\
(G)\end{array}$ & $\begin{array}{l}135 \\
(G)\end{array}$ \\
\hline \multirow[t]{2}{*}{3.} & \multirow[t]{2}{*}{$\begin{array}{c}\text { DHL } \\
(\mathrm{mhos} / \mathrm{cm})\end{array}$} & Rainy & $\begin{array}{l}147 \\
(G)\end{array}$ & $\begin{array}{l}112 \\
(G)\end{array}$ & $\begin{array}{l}93 \\
(G)\end{array}$ & $\begin{array}{l}107 \\
(G)\end{array}$ & $\begin{array}{l}98 \\
(G)\end{array}$ & $\begin{array}{l}210 \\
(G)\end{array}$ \\
\hline & & Dry & $\begin{array}{l}222 \\
(G)\end{array}$ & $\begin{array}{l}225 \\
(G)\end{array}$ & $\begin{array}{l}175 \\
(G)\end{array}$ & $\begin{array}{l}290 \\
(G)\end{array}$ & $\begin{array}{l}241 \\
(G)\end{array}$ & $\begin{array}{l}288 \\
(G)\end{array}$ \\
\hline \multirow{2}{*}{4.} & \multirow{2}{*}{$\begin{array}{c}\mathrm{pH} \\
(-) \\
\text { Dry }\end{array}$} & Rainy & $\begin{array}{l}7.0 \\
(G)\end{array}$ & $\begin{array}{l}7.0 \\
(\mathrm{G})\end{array}$ & $\begin{array}{l}6.8 \\
(G)\end{array}$ & $\begin{array}{l}7.1 \\
(G)\end{array}$ & $\begin{array}{l}6.8 \\
(G)\end{array}$ & $\begin{array}{l}7.2 \\
(G)\end{array}$ \\
\hline & & $\begin{array}{l}7.1 \\
(G)\end{array}$ & $\begin{array}{l}7.1 \\
(G)\end{array}$ & $\begin{array}{l}7.3 \\
(G)\end{array}$ & $\begin{array}{l}7.5 \\
(G)\end{array}$ & $\begin{array}{l}7.7 \\
(\mathrm{M})\end{array}$ & $\begin{array}{l}7.5 \\
(G)\end{array}$ & \\
\hline \multirow{2}{*}{5.} & \multirow{2}{*}{$\begin{array}{l}\text { Phosphate } \\
\text { (mg/lt) } \\
\text { Dry }\end{array}$} & Rainy & $\begin{array}{l}1.24 \\
(\mathrm{M})\end{array}$ & $\begin{array}{c}0.84 \\
(G)\end{array}$ & $\begin{array}{c}0.71 \\
(\mathrm{G})\end{array}$ & $\begin{array}{l}1.38 \\
(\mathrm{M})\end{array}$ & $\begin{array}{c}0.75 \\
(G)\end{array}$ & $\begin{array}{c}0.16 \\
(G)\end{array}$ \\
\hline & & $\begin{array}{c}0.125 \\
(\mathrm{G})\end{array}$ & $\begin{array}{c}0.067 \\
(\mathrm{G})\end{array}$ & $\begin{array}{c}0.146 \\
(\mathrm{G})\end{array}$ & $\begin{array}{c}0.100 \\
(\mathrm{G})\end{array}$ & $\begin{array}{c}0.154 \\
(\mathrm{G})\end{array}$ & $\begin{array}{c}0.18 \\
(\mathrm{G})\end{array}$ & \\
\hline \multirow{2}{*}{6.} & \multirow{2}{*}{$\begin{array}{c}\text { Nitrate } \\
\text { (mg/lt) } \\
\text { Dry }\end{array}$} & Rainy & $\begin{array}{c}2.89 \\
(\mathrm{G})\end{array}$ & $\begin{array}{c}0.99 \\
(G)\end{array}$ & $\begin{array}{c}0.40 \\
(\mathrm{G})\end{array}$ & $\begin{array}{l}1.97 \\
(G)\end{array}$ & $\begin{array}{c}0.83 \\
(G)\end{array}$ & $\begin{array}{c}0.24 \\
(G)\end{array}$ \\
\hline & & $\begin{array}{c}0.005 \\
(\mathrm{G})\end{array}$ & $\begin{array}{c}0.86 \\
(\mathrm{G})\end{array}$ & $\begin{array}{c}0.13 \\
(\mathrm{G})\end{array}$ & $\begin{array}{c}0.80 \\
(\mathrm{G})\end{array}$ & $\begin{array}{c}0.10 \\
(\mathrm{G})\end{array}$ & $\begin{array}{c}0.11 \\
(\mathrm{G})\end{array}$ & \\
\hline \multirow{2}{*}{7.} & \multirow{2}{*}{$\begin{array}{c}\mathrm{DO} \\
(\mathrm{mg} / \mathrm{lt}) \\
\text { Dry }\end{array}$} & Rainy & $\begin{array}{l}3.6 \\
(\mathrm{M})\end{array}$ & $\begin{array}{l}3.7 \\
(\mathrm{M})\end{array}$ & $\begin{array}{l}4.6 \\
(\mathrm{M})\end{array}$ & $\begin{array}{l}4.0 \\
(\mathrm{M})\end{array}$ & $\begin{array}{c}13.8 \\
(G)\end{array}$ & $\begin{array}{l}3.8 \\
(\mathrm{M})\end{array}$ \\
\hline & & $\begin{array}{l}1.4 \\
(\mathrm{P})\end{array}$ & $\begin{array}{l}1.0 \\
(\mathrm{P})\end{array}$ & $\begin{array}{l}4.0 \\
(\mathrm{M})\end{array}$ & $\begin{array}{l}5.8 \\
(\mathrm{M})\end{array}$ & $\begin{array}{l}5.2 \\
(\mathrm{M})\end{array}$ & $\begin{array}{l}2.2 \\
(\mathrm{P})\end{array}$ & \\
\hline
\end{tabular}

Description: $\mathrm{G}=$ Good; $M=$ Moderate; $P=$ Poor

Based on observation of water quality in Tuntang River as presented in Table 3 indicated that the value of water turbidity along the Tuntang River in the rainy season was categorized as "poor". The lowest value was obtained by Buyaran River of 30 NTU and the highest was Panjang River of 634 NTU. Meanwhile in the dry season, the lowest value was obtained by Sraten River of 3 NTU (good), Legi River of 12 NTU (moderate), and Panjang River of 15 NTU (moderate), and the highest was obtained by Buyaran River of 30 NTU (poor). Turbidity depicted optical properties of water determined based on the amount of lights which was absorbed and transmitted by the elements of water. Turbidity was caused 
by organic and inorganic matters that were suspended and dissolved such as mud and silt, as well as inorganic and organic matters such as plankton and other microorganisms (APHA, 1976); Davis and Cornwell, 1991).

On the contrary to the principle, it is expected that the high turbidity value in the rainy season was due to soil erosion resulted from sufficient catchment area. Materials of erosion from the catchment area of Lake Rawa Pening consisted of soil particles, in addition to organic matters due to its extensive Andosol characteristic. Although some of the material deposited in the inundation area, yet the turbidity level at the downstream (Buyaran River) was classified as "poor" despite its low nominal value. According to Lloyd (1985) in Hefni Effendi, 2003, the increased value of turbidity at the clear and shallow waters of 25 NTU could reduce 13-50\% of primary productivity. The increased turbidity of 5 NTU in the lake and rivers could reduce primary productivity, respectively by $75 \%$ and $3-13 \%$. Meanwhile, in the dry season the water turbidity values decreased, except in Parat River and Galeh River which were classified as "poor". It was possible that this condition was caused by stream bank erosion since the flow of the river was sourced mainly from the fountains.

Another low water quality indicator was Dissolved Oxygen (DO). Based on the analysis, the value of DO in the rainy season was 3.613.8 and classified as "moderate", except in Galeh River which was considered as "good". While in the dry season, the value of dissolved oxygen was "poor" for Parat River and Sraten River, as well as Tuntang Hilir River (Buyaran River). The condition in the rainy season was better compared to the condition in the dry season. In the rainy season, the discharge velocity is greater than in the dry season, thus the content of dissolved oxygen is greater too.

Water quality assessed from the value of total dissolved solids, electrical conductivity, $\mathrm{pH}$, phosphate $(\mathrm{P})$, and nitrate $\left(\mathrm{NO}_{3}\right)$ showed "good" quality. In accordance to the analysis, TDS in the rainy season ranged between 56$126 \mathrm{mg} / \mathrm{lt}$ and all rivers could be classified as "good", while in the dry season ranged between $83-135 \mathrm{mg} / \mathrm{lt}$, therefore all river could be identified as "good". The value of electrical conductivity in Tuntang Catchment Area was $175-639 \mu \mathrm{mhos} / \mathrm{cm}$, in which the lowest value was obtained from Legi River of $175 \mathrm{mg} / \mathrm{lt}$ and the highest was obtained from Watu River of $639 \mu \mathrm{mhos} / \mathrm{cm}$. Based on those distribution, most TDS of Tuntang River had electrical conductivity value above $200 \mu$ mhos $/ \mathrm{cm}$.

Based on the result, the value of electrical conductivity in the rainy season ranged between 93-210 $\mu \mathrm{mhos} / \mathrm{cm}$ and all rivers could be identified as "good", meanwhile, in the dry season the value ranged between 175-288 $\mu$ mhos/cm and all rivers could be classified as good. The value of $\mathrm{pH}$ in the rainy season ranged between 6.8-7.2 and all rivers could be classified as good. In the dry season, the value ranged between 7.1-7.7 (good), except for Galeh River which was classified as "moderate". N accordance to those results, the value of $\mathrm{P}$ in the rainy season ranged between 0.16-1.38 and all river could be identified as "good", except for Parat River and Panjang River which were classified as "moderate". In addition, in the dry season, the value ranged between 0.067-0.18 and all rivers could be classified as "good". Based on those result, the value of $\mathrm{NO}_{3}$ in the dry season ranged between 0.24-2.89 and all rivers could be identified as good, except for Parat River and Panjang River could be classified as moderate. Additionally, in the dry season the values ranged between $0.005-0.86$ and all rivers could be identified as good.

\section{Conclusions}

In the upstream of Tuntang sub-watershed, the inflows into Rawa Pening Lake in the dry season could be classified as "good" and "very good", except for the inflow from Kali Rengas which was classified as "poor". Even though the outflows of Lake Rawa Pening have been utilized for a variety of uses, yet the water discharge of Tuntang Hulu sub-watershed could be classified as "good" since it is supplied from Kali Tuntang $\left(5.348 \mathrm{~m}^{3} / \mathrm{sec}\right)$ in addition to from Kali Sanjaya (2.524 m³ $/ \mathrm{sec})$, Kali Watu $\left(0.009 \mathrm{~m}^{3} / \mathrm{sec}\right)$ and Kali Bercak $\left(0.367 \mathrm{~m}^{3} / \mathrm{sec}\right)$.

The potential of Tuntang River in the dry season provided by Rawa Pening Lake to the downstream was sufficiently stabile despite the discharge of Tuntang River had been widely utilized throughout its flow.

In general, the water quality of Tuntang watershed was classified as "good", except for the parameters of turbidity and dissolved oxygen. In addition the water quality assessed from Total Dissolved Solids, Electrical Conductivity, $\mathrm{pH}$, Phosphate $(\mathrm{P})$, and Nitrate $\left(\mathrm{NO}_{3}\right)$ indicated its "good" quality. 
The value of water discharge turbidity along the Tuntang River in the rainy season could be classified as "poor". The value indicated the erosion rate of the catchment area was relatively high. In the dry season, the turbidity level declined except in Kali Parat and Kali Galeh which were in "poor" state. It was possible due to the occurrence of stream bank erosion the discharge was merely derived from the water resources. It can be potentially contribute to the degradation of Rawa Pening Lake.

\section{References}

American Public Health Association (APHA). 1976. Standard Methods for the Examination of Water and Wastewater. 4th edition. American Public Health Association, Washington DC.

Badan Perencanaan Pembangunan Provensi Jawa Tengah (Bappeda Jateng). 2005.Rencana Strategis Pemerintah Provensi Jawa Tengah. Bappeda Provinsi Jawa Tengah.

Brotosusilo, A., Utari, D., Satria, A.A., 2016. Sustainability of Water Resources in the Upstream Watershed-Based Community Engagement and Multistakeholder Cooperation, in: IOP Conference Series: Earth and Environmental Science. IOP Publishing, p. 012018.

Brown, A.L.1987. Freshwater Ecology. Heinemann Eduvational Books, London. 163p.

Davis, M.L. and Cornwell, D.A., 1991. Introduction to Environmental Engineering. Second edition. McGraw-Hill, Inc., New York.

Directorate General of Land Rehabilitation and Social Forestry, Ministry of Forestry, 2009. Pedoman Monitoring dan Evaluasi Daerah Aliran Sungai.

Duan, W., He, B., Nover, D., Yang, G., Chen, W., Meng, H., Zou, S., Liu, C., 2016. Water Quality Assessment and Pollution Source Identification of the Eastern Poyang Lake Basin Using Multivariate Statistical Methods. Sustainability 8, 133.

Dugan, P.R.1972. Biochemical Ecology of Water Pollution. Plenum Press. New York.

Hefni Effendi, 2003. Telaah kualitas Air Bagi Pengelolaan Sumber Daya dan Lingkungan Perairan. Penerbit Kanisius, Yogyakarta.

Kageyama, Y., Izumi, A., Nishida, M., Yokoyama, H., 2016. Application of fuzzy C-means for understanding water quality in Lake Hachiroko, Japan. IEEJ Trans Elec Electron Eng 11, 835-837. doi:10.1002/tee.22312

Kori, K. 1976. Managing Forest for Water Supplies and Resource Conservation. Conservation Division. Forest Agency. Tokyo. Japan. In. Kunkle, S.H., and J.L Thames. Hydrological Techniques for Upstream Conservation. FAO Conservation Guide 2. FAOUN. Rome.

McMillan, M.S., 2016. Spatial and temporal analysis of land cover, climate, and lake water quality in the Matanuska-Susitna, Valley, Alaska. ALASKA PACIFIC UNIVERSITY.

Pal, J., Pal, M., Roy, P.K., Mazumdar, A., 2016. Quantitative Assessment of Water of Rudrasagar Lake, Tripura, India. European Journal of Advances in Engineering and Technology 3, 4548 .

Pawitan, H. 2002. Mengantisipasi Krisis Air di Indonesia Memasuki Abad 21. In Nugroho, S.P., S.Adi, B.Setadi.ed. Peluang dan Tantangan Pengelolaan Sumber Daya Air di Indonesia. P3-TPSLK BPPT. Jakarta.

Sawyer, C.N. and McCarty, P.L. 1978. Chemistry for Environmental Engineering. Third edition. McGraw-Hill Book Company, Tokyo.

Supangat, A.B., Paimin, P., 2007. Kajian Peran Waduk Sebagai Pengendali Kualitas Air Secara Alami. Forum Geografi 21(2).

Wang, H., Yao, J., Li, Y., 2016. An Analysis of Water Environment Factors and an Evaluation of Water Quantity of Liangzi Lake. Journal of Geoscience and Environment Protection 4, 44. 